\title{
Comparisons of myocardial strain and strain rate in patients with heart failure with preserved and reduced ejection fraction using Feature Tracking of cine MR images
}

Gangadhara Kabbli*, Lynette J Duncanson, Michael Passick, Joshua Y Cheng, Kathy Halloran, Jeannette McLaughlin, Jie J Cao

From 17th Annual SCMR Scientific Sessions

New Orleans, LA, USA. 16-19 January 2014

\section{Background}

Cardiac magnetic resonance imaging (CMR) is an important modality in heart failure evaluation. The aim of this study was to compare myocardial mechanical properties between patients in heart failure with reduced ejection fraction (HFrEF) and patients in HF with preserved EF (HFpEF).

\begin{abstract}
Methods
All participants were prospectively recruited and underwent CMR in a $1.5 \mathrm{~T}$ scanner. $\mathrm{LVEF}<45 \%$ and $\geq 45 \%$ were used to define HFrEF and HFpEF, respectively. Dilated cardiomyopathy was the primary cause for HFrEF. HF status was confirmed with B-type natriuretic peptide $(\mathrm{BNP})>400 \mathrm{pg} / \mathrm{ml}$. Patients with myocardial infarction were excluded. Myocardial circumferential strain (CST) and strain rate (CSR) was analyzed in mid LV of the short axis plane and the longitudinal strain (LST) and strain rate (LSR) in 4-chamber view of the SSFP cine images using feature tracking (CIM software, Auckland, New Zealand). LV end diastolic pressure (LVEDP) was estimated using normalized left atrial transition time from time-intensity curves of the first pass perfusion images.
\end{abstract}

\section{Results}

LVEF was $55 \pm 2 \%, 58 \pm 7 \%$ and $26 \pm 9 \%$, the median (range) BNP $15(48) \mathrm{pg} / \mathrm{ml}, 443(3250) \mathrm{pg} / \mathrm{ml}$ and 651 (2791) $\mathrm{pg} / \mathrm{ml}$, and the mean LVEDP $8 \pm 2 \mathrm{mmHg} 22 \pm$ $13 \mathrm{mmHg}$ and $22 \pm 10 \mathrm{mmHg}$, in normal controls $(\mathrm{N}=8)$,
$\operatorname{HFpEF}(\mathrm{N}=11)$, and HFrEF $(\mathrm{N}=13)$, respectively. The average CST in mid LV was $-14.6 \pm 3.4 \%,-13.8 \pm 4.3 \%$ and $-6.6 \pm 3.6 \%(\mathrm{p}<0.001)$ while the LST was $-14.1 \pm$ $1.6 \%,-9.7 \pm 5.2 \%$ and $-6.5 \pm 2.2 \%$, respectively resulting in modest CST reduction (6\%) but greater LST reduction (31\%) in HFpEF, and similar CST (55\%) and LST reduction (54\%) in HFrEF using normal controls as reference. Similar magnitude of reduction was observed in CSR and LSR for both groups. As for the rate of relaxation in early diastole there was $\sim 16 \%$ reduction in HFpEF and $\sim 50 \%$ in HFrEF for both short and long axis analysis. In contrast, the rate of relaxation in late diastole was markedly increased (119\% and $46 \%)$ in HFpEF and reduced $(27 \%$ and $16 \%)$ in HFrEF.

\section{Conclusions}

Feature tracking analysis of the CMR cine images demonstrated homogeneous strain and strain rate reduction in both the circumferential and longitudinal direction in HFrEF patients with dilated cardiomyopathy. In contrast, preserved circumferential strain of the mid LV coupled with reduced longitudinal strain and markedly increased rate of relaxation in late diastole are features of myocardial mechanical performance in HFpEF. Our findings suggest that feature tracking analysis of the cine images is promising in characterizing myocardial properties of patients with HF.

\section{Funding}

None. 
Cite this article as: Kabbli et al:: Comparisons of myocardial strain and strain rate in patients with heart failure with preserved and reduced ejection fraction using Feature Tracking of cine MR images. Journal of Cardiovascular Magnetic Resonance 2014 16(Suppl 1):P300.

Submit your next manuscript to BioMed Central and take full advantage of:

- Convenient online submission

- Thorough peer review

- No space constraints or color figure charges

- Immediate publication on acceptance

- Inclusion in PubMed, CAS, Scopus and Google Scholar

- Research which is freely available for redistribution

Submit your manuscript at www.biomedcentral.com/submit 